\title{
Intuitive spatial interaction in landscape design
}

\author{
Jonas Jakaitis, Jonas Zukas, Vilnius Gediminas Technical University, Lithuania
}

\begin{abstract}
Research in landscape architecture (LA) is an important area to improve natural, anthropogenic, social and economic sustainability. The focus point of the article is territory of historical greenery (THG) of LA, which originates as a result of interaction between material environment design and society. The study of THG problems today is based on the innate human right to live in a harmonious space of both aesthetic material and natural environment. Environmental quality criteria are important to understand the nature and human interaction embodied in LA as an expression of applied art. Therefore, urban spaces formed by the anthropogenic objects of LA, require studies of the systemic relationship between the material and natural environment and its function as a whole. Based on heuristic, qualitative and quantitative research methods and literature review of case studies, the article discusses the problems of interaction between contemporary society, historic legacy and natural processes. In this article, authors explore the natural human abilities to perceive and interact with the environment on the intuitive level. Universal design aims provide a value basis for social, cultural and functional interaction harmonization of the environment on the intuitive level. More universal and intuitive approach reveals the potential to enhance spatial interaction with the THG and to improve quality of its future management and development scenarios.
\end{abstract}

Keywords: landscape architecture; intuitive design; historical urban greenery; park art; interaction of anthropogenic and natural components

\section{Introduction}

The article focuses on the society's role analysis in the development of landscape architecture, especially of historical greenery. Main discussion is about the interaction between anthropogenic and the natural environment in context of contemporary development in intuitive design and societal activism. LA design issues are discussed in terms of aesthetics, functionality, psychological comfort, public performance, participation, etc. Investigation into these aspects is based on the scientific literature analysis, results of sociological research and surveys, conception of intuition and methods of the statistical analysis. Attention is directed towards the process of formulating, designing and implementing creative ideas for the spatial environments. The big interest in the interaction studies between anthropogenic and natural environments is revealed by the enormous variety of scientific publications and interpretations of formalized documents in the context of postmodern society. Thus, research into context of LA contemporary anthropocentric development, is of great importance, both from the point of view of cultural heritage value and community welfare [61].

Clearly, the architectural activity of landscape formation and the reinterpretation of the concept of historical greenery, requires a systematic approach and clearer definitions of the interaction between man-made and natural environment. The Lithuanian laws [39] defines historical greenery as part of a greenery system, but de facto, often it is disintegrated interaction of natural and anthropogenic components in urbanized structures.

When discussing the duality of interaction between the anthropogenic and the natural environment of Lithuanian green areas, it should be noted that the methodological analysis of LA object restoration is an area of isolated and narrow research $[32 ; 10 ; 28]$.

The heritage and especially anthropogenic uniqueness of the historical greenery is often underestimated in the formation of the LA in addition to the declared environmental goals. In this way, due to its methodological paradigm, which is poorly defined, the law on green areas is not fully implemented. Moreover, the concept of historical greenery as an art object is poorly defined in terms of utilitarianism, which is of great importance to society. Despite the abundance of studies on the science of landscape formation in Europe, deeper analytical approach to the interaction between historical greenery and the present-day societal development, is needed. Problematic issues indicate a lack of focus on the holistic research aspect. Subjectively interpreted discussions are being debated in many post-Soviet countries, including Lithuania, due to the relatively small experience of democratic involvement in the design processes and perceived uncertainties. Often, the thematic insights of the interactions are not determined by the systematic and ongoing monitoring results, but by changes in the conditions of public activism, for example to illegal or immoral activity in public spaces [47].

Related communities often rely on intuitive perception by manipulating concepts and uncertainties [15]. The systemic nature of the 
problem, for example, is evidenced by the fact that, often, the design decisions of historical green areas are not based on insufficient landscape archaeological research [29]. From the end of the 19th century, they often remained the subject of only sociological, managerial or media research $[43 ; 19 ; 59 ; 61]$. Such situation is obviously due to the passivity and low level of leadership of the coordinating institution at the national level [11]. Thus, successful development of the state's public welfare can only be achieved through a comprehensive and complex study of the various interactions between the anthropogenic and the natural environment $[30 ; 44 ; 12]$.

Horticulture in early civilizations is the result of the interplay between the anthropogenic and natural environments and is considered as an applied art and utilitarian precursor of landscape architecture. By integrating the forces of nature and the creative endeavours of society, horticulture has evolved from farm fields and practical purpose gardens to contemporary applied gardening [20]. Today utilitarian gardening activity in the Netherlands, England, Italy, Denmark, the Czech Republic, Lithuania and other countries, is favourite leisure time of modern society. In the socio-cultural context, the aesthetic features and applications of horticulture were determined by the level of interaction between anthropogenic and natural processes and the level of civilization development [33].

Many philosophers of ancient times meditated and studied in the gardens. Horticulture was not an exceptional phenomenon, but as an object of applied art, it meant everything that made a person delighted and content [57]. In the middle ages, the garden was associated with paradise [35]. Its anthropogenic and natural interactions had an application to inspire the clerical community for spiritual reflection and to meet other spiritual needs of the ecclesial community. Gardens in the middle ages were closed, focused on sacral utilitarianism. Drawing the inextricable dependence of the aesthetic expression of the Medieval Garden on the monastery residences and castles. It shows that the greenery of that time had its target user [21]. Today, no such greenery has survived in Lithuania, only speculations about the presence of Medieval Garden or nursery relics near the castle's defensive wall. Renaissance horticulture preserved its medieval sacredness and the noble representational function of utilitarianism. It still can be observed as a planning, where in the middle of Vilnius castles there is a large garden between the palace and the defensive wall [48].

Often, what we call gardens in many other languages may refer to the area planted with vegetables or fruit trees near home. However, the Historic Green Plantation in Lithuania is defined by the Law on Green Plantations as “... a large-scale greenery of enduring stylistic value or belonging to important stages of urban development, associated with significant objects or locations and important events or personalities in social, cultural and national history" [39]. This understanding moves away from the natural origins of the garden and approaches the concept of anthropogenized greenery - result of human interaction with the natural environment on functional and cultural level. To achieve the historic goal of greenery management, restoration through conservation, is often understood in modern society as preserving status quo and immutability. As a result, society perceives and interprets THG based on emotions, rumours, or hearsay [15], hence fragmented uncertainty is prevailing in ever-changing environment of postmodern culture [22].

In restoring historical greenery, it is a challenge to choose appropriate strategies for development and to find solutions that strike a balance between contemporary socio-cultural interests and natural heritage. Issues of historical green areas management should be addressed only through scientifically sound reasoning for preserving historicism, supported with the political commitment and interest of society. The aspects of park art, anthropogenic activity and the formation of social and cultural relations are the most important for historical greenery.

Kant's "Critique of Pure Reason" [31] raises the fundamental question of "what must I do?" The way in which the surrounding environment is interpreted depends on the answer to Kant's question. The world is evidently changing, and man, being completely dependent on the nature and time, cannot resist this constant change. This being supposes the temporality of live and conducts the cognition of the world through its interpretation. This is also characterized by the formation tendencies of the contemporary postmodern cultural material environment. When there are no separate artistic directions, art is everything; humanity is left to change its existence through interpretation. Therefore, in the context of contemporary greenery, knowledge is often interpretative and accompanied with intuitive responses. Intuition does not require conscious reasoning but at the same time, it participates in creating effective responses. People may intuitively feel that they know the answer but it may be difficult to rationalize the action causality. In today's diverse environment, where people with different knowledge, experience and various abilities have to interact with increasingly complex or unknown contexts, it is necessary to improve the added value of the environment spatial expression. The aims and objectives of the paper is to explore LA interactions with the human abilities to interpret environment intuitively and to examine the possibility to harmonize THG design on an intuitive level. 


\section{Methodology}

The research object is intuitive interaction between human and LA, and the objective is to evaluate the possibility to harmonize material environment's shape expression on intuitive level. In a previous article [27] authors explored the potential for the intuitive optimization of the material environment, when mechanical shape expression would provide more universal application for aesthetic and functional design. Relevance of the research into intuitive harmonization is unveiled as universal improvement of the social, cultural and functional interaction quality with the environment and it can be achieved by adapting particular shape forming techniques.

In this article, the concept of intuition is considered on the basis of cognitive sciences theoretical and practical research. Research on the problems of intuition is related to the structure of human thinking mechanisms, combining sensory abilities, psychology, cultural and environmental experiences. Human associative networks are automatically activated in the face of stimulus and parallel processing of information in implicit memory by utilizing processes prior the threshold to conscious experience. Such information processing demands complex decisions that require more effort than a conscious thought $[3 ; 13]$. Many researchers agree that intuition can be characterized as intense confidence in an intuitive feeling [25] and as a way to acquire knowledge without resorting to logic and linear analysis [51]. The modern concept of intuition states that a person experiences the world through his senses and classifies the acquired data into an environmental context (including a cultural one). Specific contexts elicit specific somatic and psychological responses and affective associations formed through learning or previous experiences. Activation of somatic states comes before consciously perceived somatic states [38]. According to Hodgkinson [25] the better structure of environment relates the to our senses, the more natural and intuitive our relationship with it is. Somatic mechanisms (sensory somatic markers) are associated with the tendency of unconscious reactions and this creates evidence in neurobiology that environmental assessments are formed not only consciously but also somatically [4; 14]. Therefore, it can be argued that the body and senses are very important factors to acquire and evaluate new information intuitively in the context of environment.

Meanings and spatial properties of objects are not entirely separable from one another but symbolic meanings can be easily detached and learned. Not all kinds of meanings are learned and evidence for that are animals and infants. Gibson points to the evidence that meanings depend on perceptions to modify the world properties and these properties depend on agent's personality and culture [17]. His motor theory of perception tells that the spatial behaviour is intimately connected with spatial perception.

Kirsh and Maglio [34] described motor activity as dual: epistemic or pragmatic. Pragmatic actions are bringing the agent closer to his goals and the purpose of epistemic actions is to obtain new information (explore the environment) by revealing what is hidden, that would eventually lead to the pragmatic actions. According to the study, motor epistemic actions are helping with the cognitive processes by reducing the amount of mental effort to get insights.

According to Gerstenberg and Tenenbaum [16], even if a person has an intuitive understanding of physical causality - what influenced it? A very important factor in shaping people's decisions is the assessment of - how it was influenced to cause different outcome. Counterfactual contrasts allow to intuitively understand the amount of one or another factor's influence, but such estimates vary because different people may regard these contrasts differently.

The ideas of intuitive theory of physics are detailed and structured. Concepts like power and moment are related through abstract laws such as the law of energy conservation. In the case of intuitive theory in psychology, beliefs, desires and actions are linked by the rational action principle - the individual will try to fulfil his desires in the most efficient way possible, taking into account their beliefs about the world $[1 ; 60]$. Gibson advocates the idea of embodied cognition [17], which would explain the human body and mind unity in order to interact with the environment - human body proposes the options for interaction.

Agent is looking for the most efficient way to interact with the surroundings and embodied cognition gives the notion of possible action affordance. Such process reduces the amount of mental activity; hence, bodily activity is directly influencing mental processes. On this theoretical basis, the intuitive interaction between human and environment are considered as human ability to perceive and simulate physical causality. This ability provides the opportunity to encode such information into environment's spatial expression, making it more easily and universally understandable on a subconscious level.

Attempts to form an intuitive spatial interaction can be observed in historical examples of the city square design. In ancient Greece and Rome, central urban agoras and forums had a perimeter of stone blocks which marked the boundaries of the public space, preventing the expansion of surrounding 
buildings and businesses, limited the access of criminals or other unwanted persons. This symbolic border was a crucial political and social marker because it clearly demarcated the place of democratic processes in society [45]. A problematic example, when medieval Western European city public spaces could have been private or simply hijacked [5]. Seating in such spaces often represented a power or served as a symbol of public order, but was also often a source of conflict between townspeople [2]. Therefore, for safety reasons, the furniture in such spaces was massive or even integrated [54]. Tiananmen Square in Beijing is traditionally shaped to reveal the structure of the city's social hierarchy, with the Gates of Heavenly Peace leading to the Forbidden City, separating ordinary residents from the world of rulers. The size of the square in terms of human scale is also very important. Large, human-scale squares, like the Red Square in Moscow or the Tiananmen Square, can psychologically generate a sense of fear. In doing so, it reveals its purpose as a more political tool or ceremony than a public recreational space [30] hence LA spatial properties can generate means to consolidate particular context.

Urban public areas have no other intended purpose besides to ensure human communication, social, cultural needs and fulfil safety objectives [27]. Therefore, quality of the historical greenery is considered in the context of these criteria. It can be enhanced by exploring the environment and human spatial interaction specifics, revealing the creative and methodical means to relate environmental mechanical causality with the human cognitive abilities.

The principles of universal design and the ensuing goals indicate factors of the environmental harmonization. The goals of universal design principles and their standards have been established and endorsed by the consensus of scientific community. These goals must be combined with the principles of universal design, to improve the quality of human life in a given environment [56;46;55]. Based on intuitive principle goals [18] and the crosswalk with principles [55], the following shape intuitive harmonization factors are established:

- The aim of cultural appropriateness - shape improves the aesthetics of an object.

- The aim of health and wellness - shape complements object's function.

- The aim of understanding - shape teaches interaction with an object.

Spatial properties of the intuitive expression variables are very diverse as well as their states (separation, centre, joint, closure, balance, etc.). These variables acquire meaning in the specific context of physical, cultural and social environment [7]. The principles of Gestalt theory are perhaps the most widely recognized in the fields of architecture and design as explaining the perception of the integrity of individual elements in the environment [8].

According to Muller [42], a person is always confronted with shape emanating functionality and even if it does not look familiar, user tries to connect it with something familiar. A semiotic understanding of shape modelling requires to understand Gestalt components from which it is made and the environment where it is placed. "Ability to gain visual information and then to project kinaesthetic sense is giving us a chance to understand the comfort of a particular object or environment" [41].

Intuitive shape perception is subliminal and takes to further and more conscious stages of information cognition and evaluation. The value-based information purposefully embedded in the stage of intuitive cognition creates preconditions for further shape Gestalt evaluation. The variables of intuitive shape expression are physical states that consist of complex elements and are perceived as Gestalt impressions. These states are described as intuitive responses to Gestalt impressions that do not require further explanation. As Gestalt impressions, they are structurally complex and therefore should be investigated in the context of a particular environment.

Abductive reasoning allowed to distinct 10 main shape expression variables, whose properties are not cultural / symbolic or specific functional origin, but are related to the mechanical conditioning, which may acquire positive values in the context of intuitive interaction:

- The proportions of the shape are rational.

- Shape reflects the properties of the materials.

- Shape is minimal.

- Shape is integral.

- The elements of the shape are contrasting.

- Shape elements are massive and rigid.

- Shape reflects the function of the object.

- Shape reveals the construction joints.

- Shape is smooth or adapted to the user.

- Shape reveals the method of use.

This analysis revealed the assumption that there are not many unique elements of shape's spatial expression, since most of them can be associated with the expression of another. In a particular context, these shape variables may be categorized as aesthetic, functional, and interactive, although they overlap in terms of intuitive design factors. Parks and other urban green zones are directly influenced by these variables. Spaces and contexts are interrelated by shape properties. In this study authors are looking for the most universal spatial expression variable, which can be applied to harmonize intuitive interaction factors. 
In late 2018 authors conducted an online survey of the shape variables in which 77 professional architects and industrial designers were participating. Participants were asked to name the most relevant shape expression variable to improve the aesthetics, complement function and to teach interaction. Survey consisted of three parts - one part for each factor. The objective was to distinguish the dominant variable, which prominently participates improving all the factors with the averages as high as possible.

Statistical calculations of survey data were performed with the GNU Affero General Public License program. Main calculations were carried out with the "Stats" module [49], "Psych" module [50] was used to calculate Cronbach's alpha coefficient, and the "Likert" module [9] was used for the descriptive statistics.

In the Methodology of estimation of the most important shape variable for a factor, the estimation of the evaluation means of respondent's answers were used to determine the most significant shape variable of all examined 10 variables for each factor. On the basis of these estimations of means, the investigated shape variables were ranked within each factor. The highest rank is assigned to the shape variable whose estimated mean is the biggest among other shape variable mean values. The most important shape variable can be determined by the following expression:

$$
m_{\mathrm{i}}^{*}=\max \left\{m_{i, j}: j \in\{1, \ldots, 10\}\right\}, i \in\{1,2,3\} .
$$

where: $m_{\mathrm{i}, \tilde{j}, j}$ is the estimated mean value of the $i$ factor of the $j$ shape variable:

$$
m_{i, j}=\frac{1}{n_{k j}} \sum_{k=1}^{n_{4 f}} x_{k}
$$

Where $i \in\{1,2,3\}$ is the number of the factor; $j \in\{1, \ldots, 10\}$ is the number of the shape variable of $i$ factors of $j$ shape variable, $x_{k}$ is $k$ evaluation of the shape variable. The ordered set (vector) of the mean values of the shape variables $X_{\mathrm{i}}, i \in\{1, \ldots, 10\}$ is as follows:

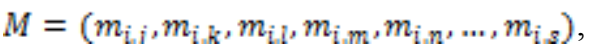

where

$m_{\mathrm{i}}^{*}=m_{\mathrm{i}, i} \geq m_{\mathrm{i}, k} \geq m_{\mathrm{i},} \geq m_{\mathrm{i}, m} \geq m_{\mathrm{i}, n} \geq \cdots \geq m_{\mathrm{i}, s}$. Then, the ordered set of the shape variables corresponds to the indexes of the ordered set of the means:

$$
I=\left(j, k_{s} l_{s} m_{s} n_{s} n_{s} s_{i, j}\right)
$$

The difference between the two estimations of the means can be statistically insignificant. In this case, the statistical hypotheses were tested:

$$
\begin{aligned}
& H_{0^{3}}: \mu_{i}^{*}=\mu_{j} \\
& H_{1}: \mu_{\mathrm{i}}^{*} \neq \mu_{j}
\end{aligned}
$$

Where $\mu_{i}^{*}$ is a mean of the shape variable whose estimated mean is the biggest, i.e. $m_{i}^{*}$. Each pair $\left(\mu_{i}^{*}, \mu_{j}\right) \in\left\{\mu_{i}^{*}\right\} \times\left\{\mu_{j}, j \in\{1, \ldots, 10\} \backslash\{i\}\right\}$, where $\mathrm{x}$ is the Cartesian product of two sets, was tested and $p_{i, j, j}$ values were calculated for each pair $\left(\mu_{i, j}^{*} \mu_{j}\right)$. If hypothesis $H_{0}$ is rejected then the highest rank 1 is attributed to the shape variable $i$ whose $m_{\mathrm{i}}=m_{\mathrm{i}}^{*}$. If the hypothesis $H_{0}$ is rejected and an alternative $H_{1}$ is then accepted, the highest rank is attributed to both $i$ and $j$ shape factors whose $p_{\mathrm{i}_{j}, j}$ value is the biggest compared to the other $p_{i, k}$ values $k \in\{1, \ldots, 10\} \backslash\{i, j\}$, since there can be more than one pair $\left(\mu_{i}^{*}, \mu_{j}\right)$ for which hypothesis $H_{0}$ is accepted.

These variables participate with different strength in enhancing one or another factor but the aim of the statistical analysis is to determine the most universal one - strongly influencing not only one e.g., aesthetics but function and interaction as well.

\section{Results and Discussion}

The statistical analysis of the survey data identified that the most statistically significant (dominant) shape variable for the object's intuitive factors harmonization is - shape reveals the method of use (Table 1).

TABLE 1

Stacking indicators of the intuitive shape expression variables

\begin{tabular}{|c|c|c|c|}
\hline Rank & Variable & Mean & $p$ Value \\
\hline 1 & V_10 & 4.051 & 1 \\
\hline 2 & V_1 & 3.957 & 0.286 \\
\hline 3 & V_7 & 3.739 & 0.015 \\
\hline 4 & V_9 & 3.65 & 0 \\
\hline 5 & V_2 & 3.495 & 0 \\
\hline 6 & V_4 & 3.227 & 0 \\
\hline 7 & V_3 & 3.192 & 0 \\
\hline 8 & V_8 & 3.098 & 0 \\
\hline 9 & V_5 & 2.949 & 0 \\
\hline 10 & V_6 & 2.457 & 0 \\
\hline
\end{tabular}

It prominently participates in revealing the way space/object should be used and enhances its functional and aesthetical properties. Meanwhile, rational proportions of shape strongly participate in enhancing the aesthetics. Variable shape reflects the function of the object also prominently participates in forming intuitive content but it is less important for the aesthetics. It has been found that the massive shape elements are the least important for all the factors of intuitive harmonization.

The dominant intuitive harmonization variable shape reveals the method of use has to be implemented into environment shape design. This variable is Gestalt impression and consists of 
implicit attributes. This impression is formed by the particular space/object's function and human interaction peculiarities. Its shape constituent parts are anthropometric data, human physical or sensory abilities and interaction place. These elements can be linked through shape altering using mechanical properties like bend - direction of force, gap anthropometric allowance to interact and etc. These restrictions are explicit and can be measured and applied in the conceptual shape modelling, providing opportunity to document, monitor, modify and test the effectiveness of the intuitive interaction.

Methodology for the integration of the intuitive design principles into the LA should investigate specifics in terms of contemporary cultural, social, psychological, functional and physical contexts. These contexts would provide value conditions for the LA spatial qualities to optimize personal, cultural and social communication.

Established dominant intuitive variable should address not only physical space properties but inevitably local social and cultural contexts. Analysis of the particular space in the context of what is the way of use provides initial design restrictions and conditions for the integration of the intuitive harmonization Gestalt. In order to reveal the spatial usage through physical shape expression it is necessary to understand design conditions of the particular space by performing analysis based on the historical legacy, local community's interests and habits.

Methodology for the integration of the intuitive design principles into the LA should investigate specifics in terms of contemporary cultural, social, psychological, functional and physical contexts. These contexts would provide value conditions for the LA spatial qualities to optimize personal, cultural and social communication.

The experimental research should apply the principles of shape mechanical formation to reveal the method for use as a THG shape intuitive harmonization variable. One of the experimental methodology's task is to determine the location of the modification in relation to the experimental object's shape. Physical components are the bearers of the function and the exact position of these fixtures may vary in each case. Therefore, research in human interaction with the shape of the environment can be attributed to the border of the functional component. The main restrictions are: the function of element and human interaction peculiarities. The amount of details may vary accordingly to the subject of interest and shape of the element should be defined by the location of functional elements and their joints because depiction of these elements are necessary to understand the placement of the shape gestalt impression.
The objective of the experiment is to test the intuitive perception of the modified LA object's shape in terms of the established intuitive harmonization variable. The practical application of monitoring is object-specific and should involve analysis of the particular object's functional and interaction values to set criterion parameters. Quantitative and qualitative research methods may be applied to monitor - how effectively shape reveals the method of use or how well human interacts with the designated object's function.

Various quantitative intuitive shape harmonization criteria can be investigated, defined by the THG object's functional and interaction values, such as: time spent in a particular place, walking distance, visitor spatial distribution, and so on. These criteria may be established by performing the analysis of the function, spatial context and human interaction peculiarities of the object. Method such as MaxDiff analysis may have advantages for the qualitative assessment when information should be perceived and evaluated on an intuitive level.

In the context of LA, socio-cultural environment, belonging, representation, and the criticality of community are greatly important in order to develop sustainable solutions. Therefore, in defining a territorial (local) community, it should address the interests of communion members [6;24]. Obviously, the development of historical greenery and its typology is more understandable to the societies with a long tradition of creating and managing them.

Strategic directions for the formation of LA should be determined and based on integral functional-economic, socio-cultural, environmental, and Genius Loci (local spirit) criteria. This will not only benefit the architectural and applied art objects, but according to Laužikaitè [37], the feeling of individual or community spiritual connection and interaction in a specific territory which is difficult to name.

Programmatic discourse with territorial (local) society should be developed at the earliest stages of the design process to formalize and define priorities for the LA objects. The Aarhus Convention [58] concerns three public rights: 1) access to environmental information; 2) participate in environmental decision-making; 3) to apply to the courts for environmental issues [52].

Žilinskas [62] identifies community as the most important local government entity consisting of residents living in a defined space - an administrative territorial unit. The author points out that community is formed by territorial community of municipalities. Thus, the modernization of greenery in a postmodern society (when the object becomes its own to the local community) is a decisive factor for public engagement and 
participation. Questions - what is important for the individual, what is important for the territorial (local) community or the wider society are becoming particularly relevant? In answering these questions, the qualities of the discourse participants must pay the utmost respect to the compatibility of law, morality and natural norms [26]. Otherwise, the extent of conflicts in historical greenery management processes will increase. For example, when discussing issues of historical greenery in public discourse, attention is drawn to the fundamental principle set out in the Florentine Charter that extensive, independent research is required before greenery management $[36 ; 40]$. In today's mass-consuming society, with its predominantly fast-paced environment, public spaces and park art is becoming an ad hoc challenge. The topic of greenery development is being speculated, and one-day goals and criteria of common goods are being debated in public. The preservation of the composition unity, structural elements, content, and details of historical greenery, whose changes are not detrimental to their essence, must today be formalized by special rules reflecting that era [23].

On the other hand, in a wider territorial (municipal) community and national context, greenfield transformations could be captured by contemporary artistic means and adapted to the needs of urban population as a choice of contemporary world views. Today, the concept of participatory society is based on human feelings and the established criteria [53]. The latter aims to connect the spaces in the interest of the community and expanding the concept of communality to the "local spirit". In this way, the "benchmarks" of urban spaces that have formed in the minds of the population and the signs of local identity could be "measured" and compared with pre-existing indicators during the monitoring process. They can be applied by Design Dialogue, Participatory Planning or Participatory Democracy [23], hence communities have the potential for successful spatial solutions based on the "local spirit" of historical greenery. The focus of participatory democracy is on active citizens who join the organizations to represent the interests of the community and influence decisions made by the government officials.

There is an opportunity to establish effective communication, when in a dialogue, members of university research teams, city municipality, and community act on their own level of competence [44]. On the other hand, there is a possibility to enhance LA of a specific area by applying principles of the intuitive design even if residents of the area are socially passive or can't establish common ground [27].
Intuitive interaction allows to form urban interaction zones - Genius Loc spaces of territorial (local) communities. Psychologists studying the phenomenon of place attachment equate rapid changes in the immediate environment with factors that lead to strong human experiences, hence feelings. Therefore, it is so important to consider the relationship of local territorial communities with the local spirit, giving preference to the arguments of people living closer together rather than the general view of society as a whole [26].

Definitely, there are regional cultural and social identity specifics but it is possible to harmonize historical greenery coexistence by integrating territorial demographic preferences and employing appropriate design methods to improve its aesthetical and functional qualities. This study argues, that LA spatial shape Gestalt can be analysed and integrated as interrelated physical elements in a particular socio-cultural context and it unlocks new potential in design optimization studies.

\section{Conclusions}

In the early civilizations horticulture formed the art of gardening by integrating the forces of nature and the creative endeavours of society. According to the principles of the International Charter of Florence, historical greenery includes architectural compositions of authorship, originality, spirit, authenticity, stylistic features, artistic and floral unity, and ethno-cultural values. They can be compared in the wider context of the evolution of European horticulture in defining the importance of greenery not only on local, national but also at European level.

Problematics of historic greenery preservation reveals itself in various contexts: legislative, historical and social. Intuitive interaction is synergy of the sensory stimulus and the particular context. As a result, it generates sensations and emotional responses. Uncontrolled emotions are disruptive force, even though laws and rationale of the historical preservation are defined and reasoned. More objective approach to intuitive harmonization of perceived stimulus can be found in universal design. Study has revealed that the Intuitive Theories demonstrate human ability to simulate Newtonian physics, and embodied cognition allows to intuitively perceive and anticipate the interaction with the environment shape. Its mechanical expression causality (Gestalt) consists of multiple combined attributes. The intuitive shape harmonization survey data analysis indicated dominant shape variable that can be effectively integrated to harmonize interaction with the environment. Intuitive shape expression gestalt is comprised of function, human interaction 
peculiarities and context. To establish socio-cultural and functional criteria and conditions for the historic greenery harmonization, it is necessary to involve community members and professionals on participatory democratic grounds.

The public sees the object of LA primarily as a "part" of the spatial structure of the territorial community, rather than as a place to be redone. Thus, the active participation of the society and consistent involvement in the project implementation processes require the consensus. However, the fact that we are observing conflict situations in a society today, does not mean that all the projects of the territorial communities cannot be properly designed and implemented. Such approach raises a demand for expertise in design management processes and more universal design techniques for controlling sensations in the context of the LA spaces.

\section{References}

1. Baker, C. L., Saxe, R., Tenenbaum, J. B. Action understanding as inverse planning. Cognition, 2009, No. 113(3), p. 329-349.

2. Barbaux, S. Urban Furniture, a New City Life. Design Media Publishing Limited. 2010.

3. Baumann, N., Kuhl, J. Intuition, affect and personality: Unconscious coherence judgments and self-regulation of negative affect, Journal of Personality and Social Psychology, 2002, No. 83(5), p. 1213-1223.

4. Bechara, A., Damasio, H., Tranel, D., Damasio, A. R. Deciding advantageously before knowing the advantageous strategy, Science, 1997, No. 275, p. 1293-1294

5. Bennett, J., Karras, R. The Oxford Handbook of Women and Gender in Medieval Europe. OUP Oxford. 2013.

6. Bentham, J. An introduction to the principles of morals and legislation. Kitchener, 1781.

7. Blake, H. M. Examining perceptions of graphic symbols across cultures: Preliminary study of the impact of culture/ethnicity. Augmentative and Alternative Communication, 2000, No. 16(3), p. 180-185

8. Bowers, S. K., Regehr, G., Balthazard, C., et. al. Intuition in the Context of Discovery, Academic Press. 1990

9. Bryer, J., Speerschneider, K. Likert: Analysis and Visualization Likert Items. $R$ package version 1.3.5. [online 05.09.2018.]. https://CRAN.R-project.org/package=likert

10. Bučas, J. Kraštotvarkos pagrindai. Kaunas: Technologija, 2001.

11. Buivydas, R. Architektūra: Pozityviai ir Negatyviai. Vilnius: Ex Atre, 2006.

12. Collins, G., Sitte, C., Crasemann, C. Camillo Sitte: The Birth of Modern City Planning. Collins Courier Corporation, 2006.

13. Dijksterhuis, A. Think different: The merits of unconscious thought in preference development and decisionmaking, Journal of Personality and Social Psychology, 2004, No. 87(5), p. 586-598.

14. Epstein, S., Pacini, R., Denes-Raj, V., Heier, H. Individual differences in intuitive experiential and analyticalrational thinking styles, Journal of Personality and Social Psychology, 1996, No. 71, p. 390-405.

15. Gaižutis, A. Estetika tarp tobulumo ir mirties. Vilnius: VDA, 2004.

16. Gerstenberg, T., Tenenbaum, J. Intuitive Theories. The Oxford Handbook of Causal Reasoning. Oxford University Press, 2017, p. 515-548.

17. Gibson, J, J. The perception of the visual world. Cambridge: The Riverside press, 1950.

18. Global Universal Design Commission. Goals. [online 12.05.2019.]. http://www.globaluniversaldesign.org/goals

19. Gražulevičiūtė-Vileniškè, I. Sociologiniai urbanizuotos aplinkos tyrimai: patirtis ir kryptys. Tiltai, 2014, No. 3, p. 35-52.

20. Habermas, J. The Structural Transformation of the Public Sphere: An Inquiry into a Category of Bourgeois Society. MIT Press, 1991.

21. Harvey, P. D. A. Mediaeval Gardens by John Harvey, Garden History, 1982, No. 10(2), p. 172-175.

22. Hassan, I. The postmodern turn: essays in postmodern theory and culture. Ohio State University Press, 1987.

23. Held, D. Models of democracy. Stanford University Press, 2006.

24. Hillery, G. A. Definition of community. Rural sociology, 1955, No. 20, p. 111-123.

25. Hodgkinson, G., Langan-Fox, J., Sadler-Smith, E. Intuition: A fundamental bridging construct in the behavioural sciences, British Journal of Psychology, 2008, No. 99(1), p. 1-27.

26. Jakaitis, J. Miesto erdvinio formavimo dalyviu diskursas šiuolaikinès demokratijos salygomis. Vilnius: Technika, 2013.

27. Jakaitis, J. Žukas, J. Intuitive design potential for optimization of material environment. Landscape architecture and art, 2018, No. 13(13), p. 82-87.

28. Jakovlevas-Mateckis, K. Miesto kraštovaizdžio architektūra. T. 3: Miesto kraštovaizdžio architektūros objektu formavimo principai: monografija. Vilnius: Technika, 2014.

29. Janonienè, R. Verkių sodai vyskupo Ignoto Jokūbo Masalskio laikais. Acta Academiae artium Vilnensis. Dailè, 2018 No. 88, p.89-105.

30. Javadi, H. Sustainable Urban Public Squares, European Journal of Sustainable Development, 2016, No. 5(3), p. 361-370

31. Kant, I. Critique of pure reason. Cambridge university press, 1998.

32. Kavaliauskas, P. Metodologiniai kraštotvarkos pagrindai. Vilnius: Academia, 1992.

33. Kelly, J. Leisure. Sagamore Publishing, L.L.C, 2012

34. Kirsh, D., Maglio, P. On distinguishing epistemic from pragmatic action. Cognitive science, 1994, No. 18(4), p. 513-549.

35. Kosmer, E. Gardens of virtue in the middle ages. Journal of the Warburg and Courtauld Institutes, 1978, p. 302-307.

36. Labeckis, D., Leparskienè, L. Paveldètas pasaulis: istorinis sodas: žurn. L.Leparskienès pokalbis su D. Labeckiu. Liaudies kultūra, 2007, No. 3.

37. Laužikaitė, M. 2019. Slypèjimas viešosiose erdvėse. [online 05.10.2019.]. https://artnews.lt/slypejimas-viesosioseerdvese-52000?fbclid=IwAR10MibgclsIpDoHiKc2539A5me3K34F7JwTwNT47raxq9qr8ez11rdI9gU 
38. Le Doux, J. E. The emotional brain. New York: Simon and Schuster, 1996.

39. Lietuvos Respublikos želdynu ịstatymas (Official Gazette 2007, No. 80-3215). [online 11.08.2019.]. https://eseimas.lrs.lt/portal/legalAct/lt/TAD/TAIS.301807

40. Middleton, W., Barba, L., Pecci, A., Burton, J., Mottram, H., Dudd, S., Lawrence, G., Stott, A. Florence Charter on Historic Gardens, Science, 1982, No. 27.

41. Monö, R.G., Knight, M., Monö, R. Design for product understanding: The aesthetics of design from a semiotic approach. Liber, 1997.

42. Muller, W. Order and meaning in design. Utrecht: Lemma Publishers, 2001.

43. Nefas, S. Local Democracy and Instruments of its Functionality in Local Self-government in Lithuania: Case Study of Alytus and Sirvintos Municipalities. International journal of arts and commerce, 2014, No. 3(2), p.70-80.

44. Pearson, J., Robbins, M. University - Community Design Partnerships Innovations in Practice. Princeton Architectural Pres, 2002.

45. Pedersen, R. Benches of the Agora. Danish Institute at Athens. 2015.

46. Petrie, H., Darzentas, J., Walsh, T. Universal Design 2016: Learning from the Past, Designing for the Future. IOS Press, 2016.

47. Pocienè, A. Socialinès tvarkos ir saugumo prielaidos mieste: aplinkos kriminologijos teorijų taikymo patirtis vakaruose ir perspektyvos Lietuvoje. Teisès problemos, 2009, No. 4(66), p.31-69.

48. Pukienė, R., Abramauskienè, R. Sodų paveldo atmintis: Lietuvos didžiųjų kunigaikščių rezidencijos Vilniaus Žemutinèje pilyje atvejis. Acta Academiae artium Vilnensis. Daile, 2018, No. 88, p. 29-46.

49. R Core Team. $R$ : A language and environment for statistical computing. $R$ Foundation for Statistical Computing. [online 03.09.2018.]. https://www.R-project.org/

50. Revelle, W. Psych: Procedures for Personality and Psychological Research. [online 14.08.2018.]. https://CRAN.Rproject.org/package $=$ psychVersion=1.8.4.

51. Rew, L. Intuition: Nursing knowledge and the spiritual dimension of persons, Holistic Nurse Practitioner, 1989, No. 3(3), p. 56-68.

52. Sands, P., Peel, J. Principles of international environmental law. Cambridge University Press, 2012.

53. Sanoff, H. Community participation methods in design and planning. John Wiley \& Sons, 1999.

54. Schmidlin, C., Gerner, C. Gothic. Tandem Verlag GmbH, 2008.

55. Steinfeld, E., Maisel, J. Universal Design: creating inclusive environments. John Wiley \& Sons, 2012.

56. Trends in Universal Design: An anthology with global perspectives, theoretical aspects and real world examples. Norwegian Directorate for Children, Youth and Family Affairs, 2013.

57. Turner, T. Garden history: Philosophy and design 2000 BC-2000 AD. Routledge, 2005.

58. United Nations Convention on Access to Information, Public Participation in Decision-making and Access to Justice in Environmental Matters. [online 04.09.2019.]. https://treaties.un.org/doc/Treaties/1998/06/19980625\%200835\%20AM/Ch_XXVII_13p.pdf

59. Vanagas, J. Miesto sociologijos pagrindai. Vilnius: aldorija, 1996.

60. Wellman, H. M. The child's theory of mind. Cambridge: The MIT Press, 1992.

61. Zaleskienè, E., Gražulevičiūtè-Vileniškè, I. Guidelines for Landscape Management in the Areas of Rural-Urban Interface: Continuity and Innovation. Architecture and Urban Planning, 2014, No. 9, p. 21-26.

62. Žilinskas, G. Ivadas i viešaji valdyma. Kaunas. Technologija, 2009.

\section{AUTHORS:}

Jonas Jakaitis, Professor, Head of the Design department, Vilnius Gediminas Technical University. Address: Pylimo g. 26 / Traku g. 1, LT-01132 Vilnius, Lithuania, +370 64092987, jonas.jakaitis@vgtu.lt. He holds a $\mathrm{PhD}$ in area of theory and methodology of art. Jakaitis is a certified architectural-designer expert, an expert at the Lithuanian Evaluation Centre of the Quality of Studies and expert at the Design Council of UK. He is a member of the Lithuanian Association of Landscape Architects and of the Lithuanian Association of Architects. J.Jakaitis is on the editorial board of science periodicals "Civil Engineering and Architecture" (Horizon Research Publishing, USA), "The Educational Review", (USA), "Smart Construction Research", (Singapore), "Architecture and Design Review" (Singapore), "Editorial office of Landscape Architecture and Regional Planning" (Science Publishing Group is an independent international publisher) etc. Fields of interest: landscape architecture, urban planning and design, industrial design in urban space, history of architecture and design, society participation in urban planning and sustainable formation of living environment.

Jonas Zukas, PhD student, Lecturer of Industrial Design, Vilnius Gediminas Technical University. Address: Pylimo St. 26 / Traku St. 1, LT-01132 Vilnius, Lithuania, +370 52512363, jonas.zukas@vgtu.lt Fields of interest: principles of the intuitive design, spatial aesthetics, industrial design and sculpture.

Kopsavilkums. Pētījumiem ainavu arhitektūrā ir svarīga loma, kas nosaka dabisko, antropogēno, sociālo un ekonomisko ilgtspējību. Rakstā galvenais akcents tiek likts uz vēsturisko apstādījumu teritoriju, kas radusies materiālās vides dizaina un sabiedrības mijiedarbības rezultātā. Vides kvalitātes kritēriji ir svarīgi, lai saprastu dabu un cilvēku mijiedarbību, kas iemiesota ainavu arhitektūrā kā lietiškās mākslas izpausme. Balstoties uz heiristisko, kvalitatīvo un kvantitatīvo pētījumu metodēm un literatūras izpēti, rakstā tiek analizētas mūsdienu sabiedrības mijiedarbības, vēsturiskā mantojuma un dabisko procesu problēmas. 